Limnol. Rev. (2014) 14,1: 45-50

DOI 10.2478/limre-2014-0005

\title{
Restoration and assessment of water resources of drained lakes. Example of Chełmno Lakeland (Poland)
}

\author{
Mariusz Ptak \\ Institute of Physical Geography and Environmental Planning, Adam Mickiewicz University, Dzięgielowa 27, 61-680 Poznań, Poland; \\ e-mail: marp114@wp.pl
}

\begin{abstract}
Based on cartographic materials, three lakes drained in the previous centuries have been reconstructed. It was found that by restoring them to their original state their total surface area would rise by 140 ha. Knowing the water surface level, determined on the basis of the range of peat soils and contour lines, the author reconstructed the bathymetric plans of the lakes. This, in turn, allowed a determination of the volume of water stored in their basins. It amounted to ca. 2.5 million $\mathrm{m}^{3}$. The approach adopted in the paper draws attention to an important element, i.e. to lakes which no longer exist in Poland and which have disappeared as a result of hydrotechnical works. Their restoration to their original state could become an important link in water retention and delaying the land phase of the water cycle. Activities aimed at retaining water in reception basins are carried out in Poland, among others, through the small retention program. Within this project, facilities such as artificial storage reservoirs are being built. In the light of the foregoing, before making a decision to build such a reservoir, it is worth considering the possibility to restore the natural components of the environment, which is more justifiable, both from the point of view of subsequent functioning of the environment and economic factors.
\end{abstract}

Key words: water resources, lake retention, drained lakes, Chełmo Lakeland

\section{Introduction}

As a result of an expansive adaptation of the environment by humans, its natural features have been drastically transformed. Water attracted special interest. This interest was twofold: on the one hand, water determined economic growth, on the other, it became a certain limitation on settlement, the development of agriculture, etc. In the context of the water resources of the hydrosphere, the latter was of key importance. The consequences of extensive soil-improving works, which begun in Poland as early as in the $18^{\text {th }}$ century, can still be seen today. As a result of extension of the network of drainage ditches and canals, water levels in many rivers and lakes have been significantly reduced. Some of them have been lost forever. Kaniecki (2013) and Choiński et al. (2012) give examples of such phenomena. Ptak et al. (2013) describe an interesting case, where Lake Jelenino, with the total surface area of 500 ha, was completely drained as a result of hydrotechnical works. However, in the context of water shortages in Poland, the information about the water resources lost as a result of draining is more important, since lakes constitute perfect water reservoirs in the environment, having a positive impact on the water balance. Within the framework of the program for extending small retention, initiated in the ' 90 s of the $20^{\text {th }}$ century, weirs are being built on natural lakes and artificial storage reservoirs are being constructed. The latter give rise to many controversies, while the environmental impact of such decisions in several or several dozen years is difficult to assess. Therefore, apart from building new reservoirs, other methods of increasing retention should be sought. The restoration of natural lakes drained in the past centuries to their original state could provide a solution to this problem. In the paper, based on the examples of selected lakes in the Chełmno Lakeland (Fig.1), the possibility to increase water resources retention in the basins of these lakes was evaluated. Figure 2 presents the situation in the early $20^{\text {th }}$ century. 


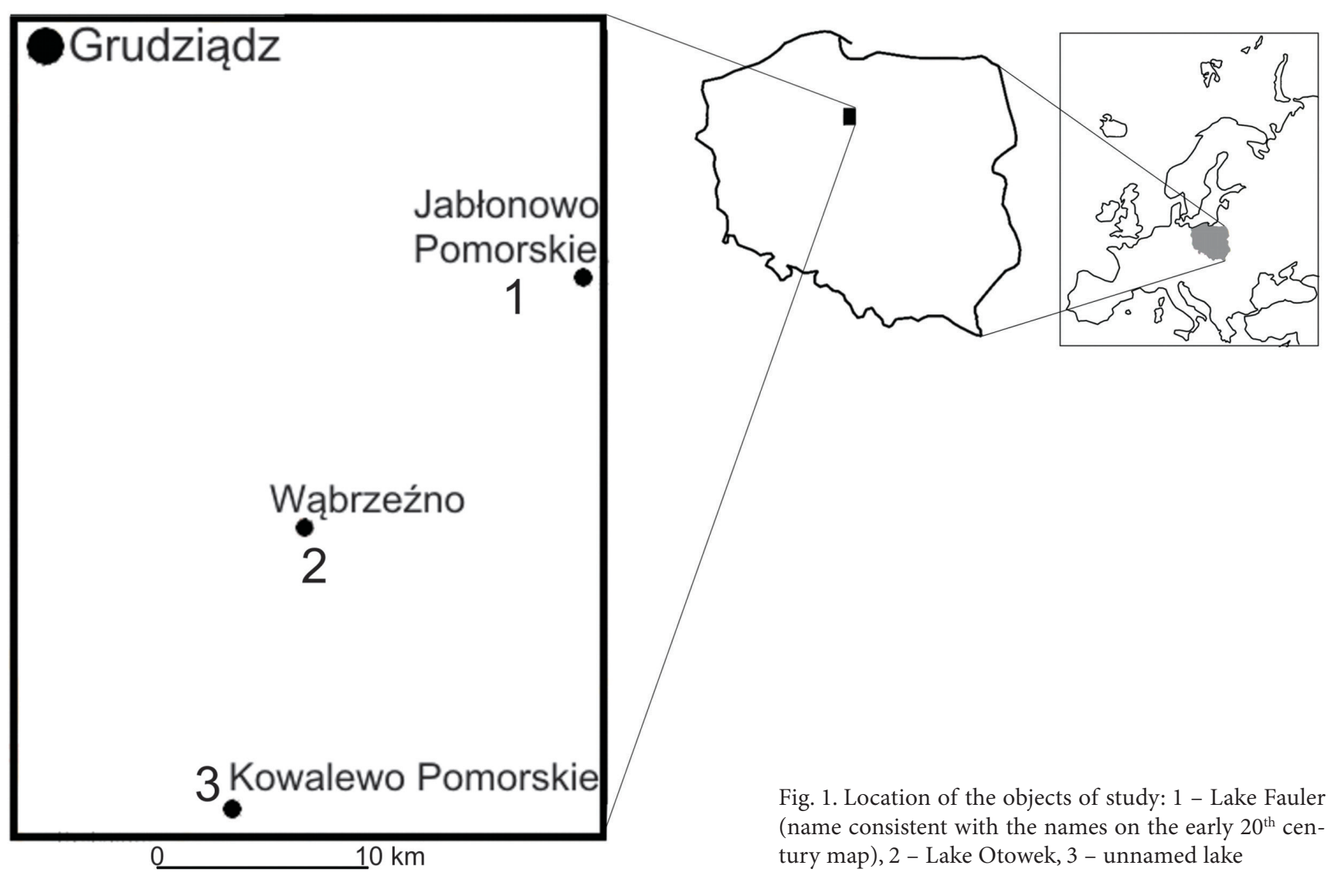

\section{Material and methods}

The evaluation of the water resources lost as a result of draining of lakes, presented in the paper, was based on cartographic materials from the early 20th century (1:25000 topographic map, 1:25000 geological map) and 1:10000 topographic maps from the late 20th century. On the basis of the occurrence of peat (Fig. 3) and distribution of contour lines, the range of drained lakes and their surface area were calculated. The calculations were made using the MapInfo program.

Knowing the water surface level, the author was able to calculate the volume of the lake basins, treating particular contour lines as isobaths. The volume was calculated using Penck's method. According to this method the lake volume is a sum of partial volumes corresponding to the area between the subsequent isobaths. The volume is calculated as that of the truncated cone of the bases delineated as the two subsequent isobaths. The height of the cones equal to the difference between these two isobaths.

\section{Results and discussions}

The total surface area of the three drained lakes amounted to nearly 140 ha. Fauler Lake with the surface area of 60.7 ha was the largest, followed by Lake Otowek - 45.3 ha, and an unnamed lake (near Kowalewo Pomorskie) - 33.2 ha. The total volume of the three lake basins amounted to ca. 2.4 million $\mathrm{m}^{3}$. Fauler Lake could retain the largest amount of water (1.2 $\left.\mathrm{hm}^{3}\right)$, followed by Lake Otowek $\left(0.61 \mathrm{hm}^{3}\right)$ and the unnamed lake $\left(0.54 \mathrm{hm}^{3}\right)$. Fig. 4 presents the bathymetric plans of the previously mentioned lakes.

In the context of environmental impact, the second value, i.e. the one referring to the amount of water "stored" in the presented lakes, deserves to be emphasized, since Poland has the lowest quantity of water resources per capita in Europe (ca. $1600 \mathrm{~m} 3 \mathrm{yr}^{-1}$ ). According to the Hydrological Atlas of Poland (Stachý 1987), the analyzed lakeland has one of the lowest average amounts of precipitation in the country (ca. 550 $\mathrm{mm} \mathrm{yr}-1)$, which translates into one of the lowest values of specific discharge (3-4 $\left.\mathrm{m}^{3} \mathrm{~s}^{-1} \mathrm{~km}^{-2}\right)$. Therefore, 

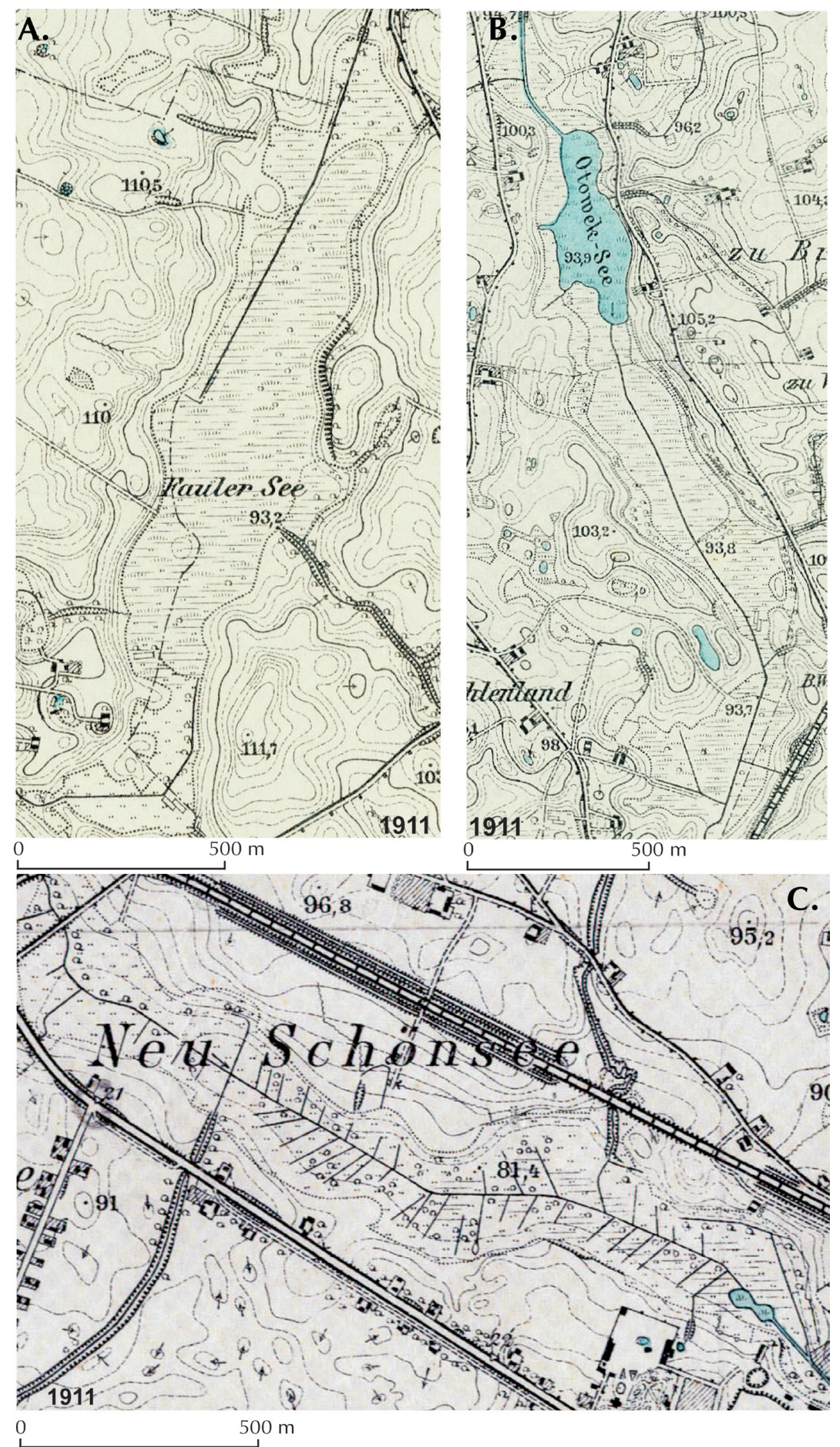

Fig. 2. Terrain in the vicinity of the now non-existent lakes in the early $20^{\text {th }}$ century (A. Fauler Lake, B. Otowek Lake, C. Unnamed Lake) 


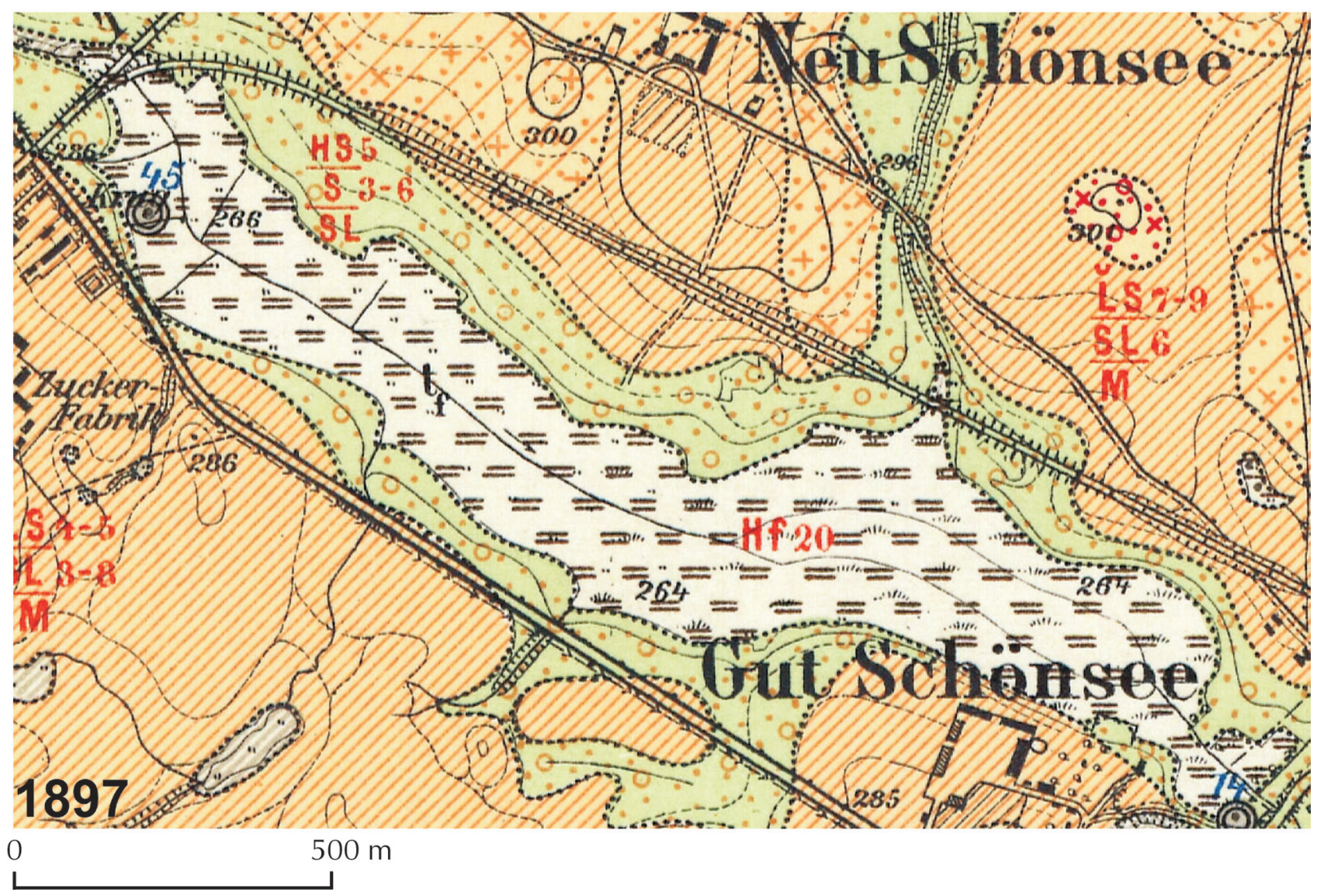

Fig. 3. The range of the now non-existing lake near Kowalewo Pomorskie - a fragment of a geological map from the early $20^{\text {th }}$ century (Geologische Karte von Preussen, 1:25000, sheet: Schoensee).

the need to retain water during the land phase of the water cycle - especially in the areas which experience water shortages - becomes of key importance.

As has already been said, an improvement of the existing state gave rise to the broadly-understood small retention program, launched in the late 20th century. Not only does it drastically change the environment, which could cause unpredictable damage to the relations between its particular components (representing both living and inanimate nature), but is also a costly undertaking. In the light of the foregoing, before deciding on interfering with the hydrosphere on a large scale, it is worth looking for other (less invasive) methods of achieving the pursued goals. Restoring natural lakes drained several or several dozen years ago to their original state could be a solution to this problem. The decisions to liquidate lakes taken at the time were motivated chiefly by the desire to increase the area of farmland. However, the benefits of a such newly created farmland were often short-lived. The areas of thus-obtained hydrogenic land would gradually lose their physical and chemical properties, as a result of the change of the environment in which they were found. This, in turn, was associated with additional expenses on maintaining high quality of land. Koc et al. (2005) emphasizes that the undertakings aimed at restoring natural water reservoirs should be synchronized with the needs of farmsteads and agritourism farms (electricity production, lake fishing, landscape quality improvement for recreational and leisure purposes). Bearing the foregoing factors in mind, it is worth considering what the most beneficial option would be: seasonal farming of land which is often of low fertility or year-round operation of a lakeside boardinghouse. The quality of water in such "reborn" lakes gives rise to certain concerns. However, as shown in one of the few works dealing with this subject matter (Sobczyńska-Wójcik 2009), a quarter of a century after its restoration, Lake Nowe Włóki is a stable ecosystem, with class 2 water purity. Subsequently, the same author claims that the restoration of the said lake was reasonable and could contribute to improving the country's water resources. 

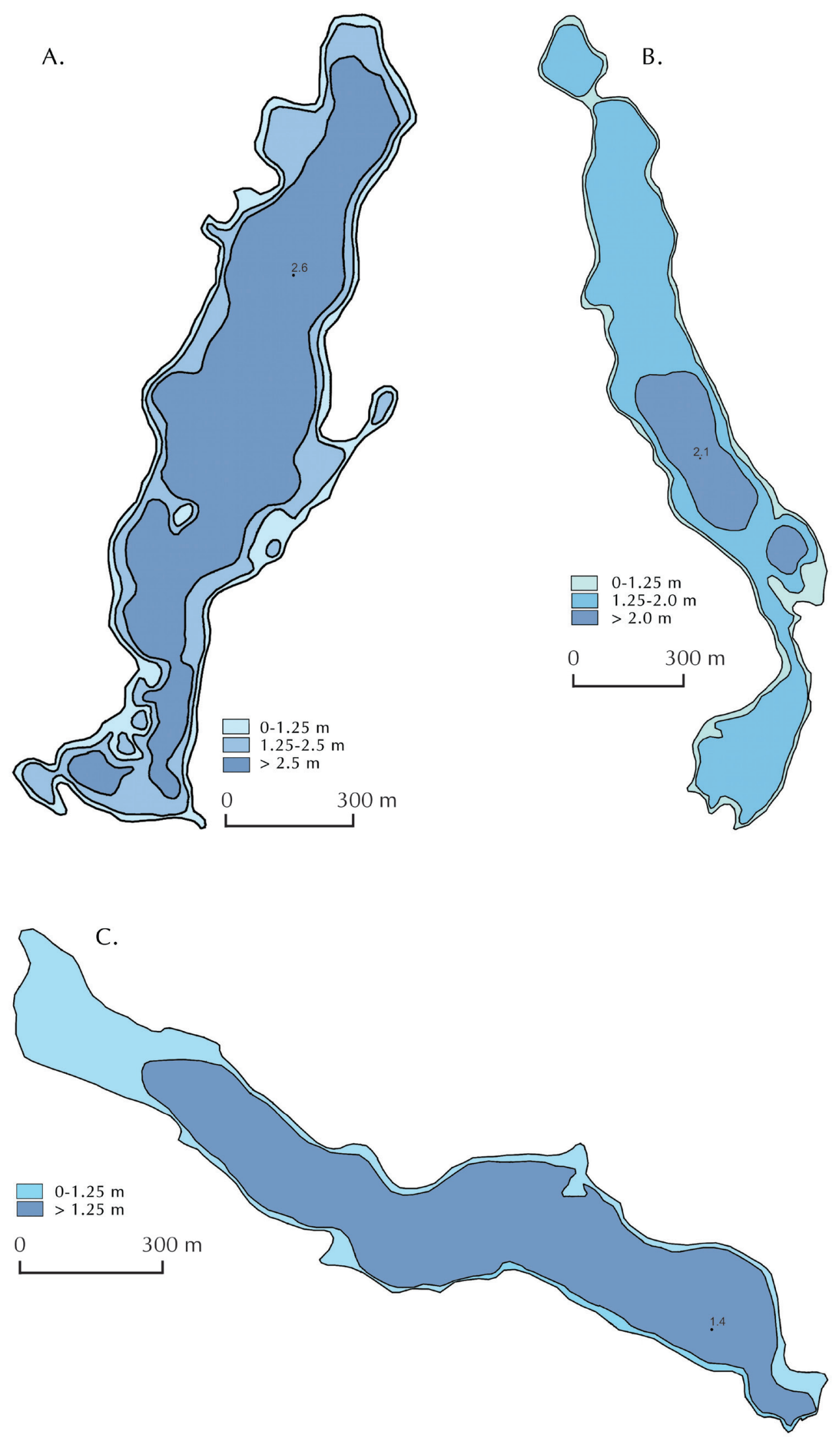

Fig. 4. Reconstructed bathymetric plans of the now non-existing lakes. A - Lake Fauler, B - Lake Otowek, C - unnamed lake 


\section{Conclusions}

The evaluation of the water resources of the three lakes presented in the paper shows that the restoration of bodies of water drained as a result of human activity could become an important element in delaying the outflow of water from particular reception basins. The extent of lake draining works carried out in the country was large (as shown in the works quoted in the opening section of the paper). It goes without saying that such renaturalization is not always possible (e.g. for administrative and legal reasons). However, before deciding on expanding the hydrotechnical infrastructure, it is worth examining the land in order to find out whether it used to have a lake. It is better to restore a natural element of the environment than to drastically change it.

\section{References}

Choiński A., Ptak M., Strzelczak A., 2012, Examples of lake disappearance as an effect of reclamation works in Poland, Limnol. Rev. 4: 161-167.

Kaniecki A., 2013, Zanikłe jeziora Pojezierza Poznańskiego (Disappearance of lakes in the Poznań Lake District), Bad. Fizjogr. 4(A63): 91-106 [in Polish, English summary].

Koc J., Nowicki Z., Sidoruk M., 2005, Problemy renaturalizacji jezior na przykładzie jeziora Ardung w zlewni Łyny (Problems of the lake renaturization. A case study of Lake Ardung located in the Łyna River basin), Inż. Ekol. 13: 11-21 [in Polish].

Ptak M., Choiński A., Strzelczak A., Targosz A., 2013, Disappearance of Lake Jelenino since the end of XVIII century as an effect of anthropogenic transformations of natural environment, Pol. J. Environ. Stud. 22(1): 191-196.

Sobczyńska-Wójcik K., 2009, Jakość wód odtworzonego zbiornika Nowe Włóki jako wskaźnik skuteczności tego zabiegu (Quality of waters of the restored Nowe Włóki reservoir as an indicators of the effectiveness of restoration), Proc. ECOpole 3(2): 509-514 [in Polish, English summary].

Stachý J. (ed.), 1987, Atlas Hydrologiczny Polski. Tom I (Hydrological Atlas of Poland. Part I), Wyd. Geol., Warszawa, p. 79 [in Polish]. 